\title{
CORPORATE SOCIAL RESPONSIBILITY DAN EARNINGS MANAGEMENTS: SUDUT PANDANG STAKEHOLDER THEORY
}

\author{
Novi Kantasilo Tan ${ }^{1}$, Permata Ayu Widyasari ${ }^{2 *}$, Maria Eugenia Hastuti ${ }^{3}$ \\ ${ }^{1,2,3}$ Universitas Surabaya, novi.kantasilo@gmail.com, \\ permataayu@staff.ubaya.ac.id(Corresponding Author), mhastuti@staff.ubaya.ac.id
}

\begin{abstract}
ABSTRAK
Tujuan dari penelitian ini menguji pengaruh dari tanggung jawab sosial perusahaan (corporate social responsibility) terhadap manajemen laba (earnings management). Sebagai variable dependen, manajemen laba di proksikan menggunakan diskresionari akrual sedangkan tanggung jawab social perusahaan, sebagai variable independen, diukur berdasarkan Global Reporting Initiative (GRI) yang disesuaikan dengan perekonomian Indonesia. Penelitian ini menggunakan sample perusahaan manufaktur yang terdaftar di bursa efek Indonesia tahun 2012-2016, dengan jumlah 423 observasi. Dengan menggunakan metode regresi linier, penelitian ini menunjukan hasil bahwa tanggung jawab social perusahaan menpunyai pengaruh negatif terhadap manajemen laba. Untuk mempertegas hasil ini, peneliti melakukan analisa tambahan dengan mengubah pengukuran tanggung jawab social perusahaan. Dummy 1 digunakan untuk perusahaan yang mengungkapkan CSR diatas rata-rata dan 0 untuk perusahaan yang mengungkapkan CSR di bawah rata-rata. Hasil menunjukan hubungan signifikan negatif tanggung jawab social perusahaan terhadap manajemen laba. Hutang, Ukuran, dan ROA perusahaan tidak mempunyai pengaruh signifikan terhadap manajamen laba.
\end{abstract}

Kata kunci: tanggung jawab sosial perusahaan, manajemen laba, teori stakeholder

\begin{abstract}
This study aims to examine the effect of corporate social responsibility on earnings management. Earnings management, as the dependent variable, is proxied by discretionary accruals (DACC). While corporate social responsibility, as an independent variable, is measured by adjusted GRI standards. This study uses sample manufacturing companies listed on the Indonesia Stock Exchange during the period 2012-2016. The number of samples used in this study amounted to 423. The findings, based on the linear regression method, indicate that corporate social responsibility has a significant negative effect on earnings management. To conform to the result, a robustness test was performed and found a significant negative relationship between dummy corporate social responsibility and earnings management. Dummy 1 for the company which disclose CSR above average, 0 for the company disclose CSR below average. So it can be concluded that the company that focuses on corporate social responsibility has lower earnings management. For leverage, size, and ROA, as control variables, showed no significant effect on earnings management.
\end{abstract}

Keywords: Corporate Social Responsibility, Earnings Management, stakeholder theory.

Naskah diterima: 29-05-2020, Naskah dipublikasikan: 30-11-2020

\section{PENDAHULUAN}

Tanggung jawab sosial (Corporate Social Responsibility/ CSR) yang dilakukan berbagai badan usaha merupakan bentuk bukti kepedulian badan usaha dari segi sosial, ekonomi dan lingkungan. Di Indonesia Undang-undang No. 40 tahun 2007 telah mengatur peraturan yang mewajibkan Perseroan Terbatas (PT) yang menggunakan sumber daya alam untuk melaksanakan tanggung jawab sosial dan lingkungan. Berbagai perusahaan melakukan CSR bukan hanya bentuk 


\section{JURNAL AKUNTANSI, Vol. 9, No. 2, November (2020)}

kepedulian badan usaha terhadap lingkungan dan seluruh stakeholder, namun juga sebagai salah satu cara untuk menyukseskan bisnis. CSR yang dilakukan badan usaha memberikan kesan positif di mata stakeholder. Klien (2015) menyatakan bahwa CSR berkembang sebagai alat untuk membangun reputasi atau sebagai perlindungan badan usaha terhadap kerusakan reputasi. Kerusakan reputasi badan usaha dapat terjadi karena adaya tidak seperti manipulasi laporan keuangan (Earnings Management/ EM).

EM dapat menunjukan kinerja perusahaan tidak jujur yang dapat menyesatkan stakeholder, dan CSR digunakan sebagai topeng atau tameng untuk melakukan EM. Berbagai penelitian untuk melihat hubungan antara EM dan CSR telah dilakukan peneliti-peneliti sebelumnya. Terdapat yang menyimpulkan bahwa CSR tidak memberikan pengaruh terhadap EM, CSR memberikan pengaruh positif terhadap EM, dan juga CSR memberikan pengaruh negatif terhadap EM. Berbagai penelitian yang dilakukan saling bertolak belakang dan tidak konsisten (research gap). Hal ini yang menjadikan berbagai pertanyaan, sehingga penulis melakukan penelitian ini.

Gras-Gil et al. (2016) salah satu yang meneliti hubungan antara CSR dengan EM dan menemukan bahwa perusahaan yang berkomitmen dalam melaksanakan CSR akan kurang terlibat dalam EM karena perusahaan yang banyak melakukan CSR cenderung mendorong hubungan jangka panjang dengan stakeholder daripada memaksimalkan keuntungan jangka pendek. Gras-Gil et al. (2016) juga mengungkapkan bahwa ketika perusahaan banyak melakukan CSR, dana perusahaan akan terserap untuk melakukan CSR sehingga dana untuk melakukan EM akan kurang dan akan menurunkan minat melakukan EM. Sembiring (2017) melakukan penelitian antara CSR dengan EM dan menemukan bahwa perusahaan yang melakukan CSR membuat pelaporan keuangan lebih transparan dan dapat diandalkan untuk para investor, serta memotivasi pihak manajer untuk bersikap jujur, dapat dipercaya, dan beretika. Sehingga perusahaan yang berkomitmen dalam CSR cenderung menunjukkan EM yang rendah.

Dari latar belakang yang telah diungkapkan penelitian ini dilakukan dengan mengangkat topik mengenai hubungan antara CSR dan EM Peneliti melakukan penelitian terhadap perusahaan go public sektor manufaktur yang terdapat dalam Bursa Efek Indonesia. Penelitian ini menggunakan sampel badan usaha sektor manufaktur karena berdasarkan pengungkapan Kowanda (2017) bahwa badan usaha manufaktur dianggap sebagai perusahaan yang kegiatannya mengelolah bahan mentah menjadi barang jadi sehingga dalam aktivitas pengelolahannya tentunya selain menghasilkan produk secara langsung maupun tidak langsung juga menghasilkan limbah ataupun polusi seperti pemanasan global, penurunan kualitas lingkungan, dan berbagai kerugian lainnya, sehingga perusahaan manufaktur memiliki tanggung jawab yang lebih besar dalam menjaga lingkungan serta dalam melaksanakan CSR badan usaha harus menginformasikan segala upaya yang telah dilakukan dalam laporan tahunannya berupa pengungkapan. Pemilihan sampel badan usaha manufaktur juga disebabkan perusahaan dalam satu jenis industri yaitu manufaktur kecenderungan memiliki karakteristik akrual yang hampir sama.

Berdasarkan latar belakang tersebut peneliti melakukan studi ini dengan tujuan mempelajari hubungan antara CSR dan EM pada perusahaan manufaktur yang terdaftar di Bursa Efek Indonesia (BEI) periode 2012-2016 sebagai sampel penelitian.

\section{Research questions}

Penelitian ini mengangkat sebuah research question "Apakah penerapan corporate social responsibility berpengaruh negatif tehadap earnings management?”

\section{KAJIAN LITERATUR \\ Literature Review and Hypothesis Development}

Segala praktik dalam suatu perusahaan tentunya akan memberikan dampak terhadap stakeholder. Praktik positif maka akan memberikan dampak positif terhadap stakeholder, begitu pula praktik negatif maka akan berdampak negatif terhadap stakeholder. Salah satu praktik negatif yang berdampak cukup besar terhadap stakeholder adalah praktik earnings management (EM). Dimana praktik earnings management dapat menyesatkan stakeholder dengan informasi laporan keuangan yang salah, dan hal ini berdampak serius pada pemegang saham, kreditur, karyawan, dan masyarakat 


\section{JURNAL AKUNTANSI, Vol. 9, No. 2, November (2020)}

(Zahra et al. 2005). EM dapat memiliki efek pada harga saham suatu perusahaan, dan nantinya harga saham akan menurun sebagai akibat dari praktik manajemen laba. Oleh karena itu, pengungkapan CSR dilakukan perusahaan untuk bertanggung jawab kepada stakeholder dan melaporkan keberlangsungan pengembangan bisnis mereka (Gras-Gil et al., 2016).

Berdasarkan Undang-undang No. 40 tahun 2007 tentang perseroan terbatas, Tanggung jawab social perusahaan (CSR) adalah suatu wadah kegiatan bisnis perusahaan untuk meningkatkan kesejahteraan karyawan maupun keluarga komunitas setempat namun memberikan keuntungan perusahaan secara financial. Menurut Kotler dan Lee (2005) manfaat CSR bagi perusahaan yaitu meningkatkan pendapatan dan pangsa pasar; memperkuat posisi brand; meningkatkan image dan kekuasaan perusahaan; meningkatkan kemampuan untuk menarik, memotivasi, dan memperoleh karyawan, mengurangi biaya operational; dan meningkatkan daya tarik terhadap investor dan analis keuangan. CSR dapat memberikan sisi positif dengan berkurangnya tingkat kecurangan. Namun juga dapat sebagai topeng untuk menutupi hal-hal yang tidak ingin diketahui oleh publik seperti kecurangan yang banyak dilakukan oleh perusahaan yaitu earnings management (EM). Pengungkapan CSR dapat menjadi kesempatan manajemen untuk menutupi kesalahan yang dilakukannya.

EM adalah intervensi manajemen dengan sengaja dalam proses penentuan laba, biasanya untuk memenuhi tujuan pribadi. EM dibagi menjadi 2 jenis yaitu Accrual Earnings Management, dan Real Earnings Management. Real Earnings Management adalah Praktik EM yang dilakukan oleh perusahaan melalui manipulasi penjualan, pengurangan beban diskresionari atau dengan produksi yang berlebihan (overproduction).

Accrual Earnings Management adalah Praktik EM yang dilakukan oleh perusahaan melalui komponen akrual dalam laporan keuangan. Kebijakan akrual dibagi menjadi 2 yaitu Discretionary Accrual dimana merupakan salah satu cara atau kebijakan yang dilakukan oleh manajer untuk mempengaruhi laba atau kebijakan yang dilakukan manajer untuk mempengaruhi laba perusahaan sesuai dengan keinginannya melalui penggunaan accruals, dan Non-discretionary Accrual dimana merupakan accruals yang tidak dipengaruhi oleh manajer, karena terdapat aturan yang terkait dengan aktivitas bisnis perusahaan, kebijakan NDAC dilakukan dengan cara yang wajar dan tunduk pada suatu standar atau prinsip akuntansi yang berlaku umum.

Faktor-faktor yang mengendalikan perbedaan dalam insentif pengelolahan laba adalah Size (Proxy ukuran perusahaan), Leverage (Penggunaan aset dan sumber dana oleh badan usaha yang memiliki biaya tetap dengan maksud agar meningkatkan keuntungan potensial pemegang saham (Frasen dan Orminston, 2013), dan ROA (Proxy untuk profitabilitas perusahaan).

\section{Pengaruh Corporate Social Responsibility Terhadap Earnings Management}

Menurut stakeholder theory, seluruh stakeholder berhak untuk mengetahui keadaan perusahaan sebenar-benarnya tanpa ada yang ditutupi ataupun dimanipulasi. Berdasarkan penelitianpenelitian yang ada menunjukkan bahwa masih banyak terdapat perusahaan yang menutup-nutupi kondisi perusahaan yang sebenarnya, dengan tujuan mempertahankan keberlangsung perusahaan. Namun hal ini tentunya akan membuat reputasi perusahaan menjadi buruk ketika perusahaan telah diketahui melakukan manipulasi.

Reputasi suatu perusahaan akan baik dan menerima kesan positif dari para stakeholder ketika perusahaan menunjukkan tanggung jawabnya dalam bentuk corporate social responsibility (CSR). Ketika suatu badan usaha berfokus pada CSR akan menghindari EM, dimana EM akan menjadi reputasi perusahaan yang telah baik menjadi hancur dan sulit untuk membangun reputasi yang baik kembali.

Penelitian Gras-Gil et al. (2016) meneliti hubungan antara CSR dengan EM, dan menemukan hubungan negatif antara CSR dengan EM. Dengan kata lain, adanya CSR yang baik maka akan terjadi rendahnya EM. Begitu pula dengan penelitian Sembiring (2017), Wulandari (2015), Scholtens dan Kang (2012), dan Kim et al. (2012) dimana menemukan adanya hubungan negatif antara CSR dengan EM. Sedangkan Yip et al. (2011) menemukan 2 kesimpulan yaitu pada oil and gas industry menemukan hubungan negatif antara CSR dan pada food industry ditemukan hubungan positif. Prior et al. (2008) juga melkaukan penelitian antara CSR dan EM menemukan bahwa CSR dan EM tidak saling berhubungan satu dengan lainnya. 


\section{JURNAL AKUNTANSI, Vol. 9, No. 2, November (2020)}

Earnings management dapat dilakukan untuk meraih kepuasan dari stakeholder. Berdasarkan teori stakeholder, perusahan lebih memilih untuk memaksimalkan return on investment dalam jangka panjang ketimbang keuntungan jangka pendek. Kegiatan csr - contohnya menjalankan bisnis yang berkelanjutan (sustainable) - merupakan rencana strategis untuk mencapai return on investment jangka panjang (Gras-Gil et al, 2016). Kegiatan CSR juga membuat penggunaan sumber daya menjadi lebih efektif sehingga berpengaruh positif ke kinerja keuangan perusahaan (Orlitzky et.al, 2003). Sehingga, tanpa melakukan earnings management, perusahaan yang berpartisipasi pada kegiatan CSR sudah dapat memuaskan stakeholder.

Berdasarkan uraian tersebut, maka hipotesis yang diajukan adalah:

H1: Corporate social responsibility memiliki pengaruh negatif terhadap earnings management.

\section{METODE PENELITIAN}

\section{Populasi dan Prosedur Pengambilan Sampel}

Sampel penelitian diambil dengan non probability sampling dengan teknik purposive/ judgement sampling. Target dan Populasi dalam penelitian ini adalah sektor manufaktur yang terdaftar di BEI, dan memenuhi syarat yaitu menerbitkan laporan keuangan dan laporan tahunan, dan menggunakan mata uang rupiah.

\section{Model Specification}

Untuk menguji H1 apakah CSR berpengaruh negatif terhadap pengungkapan EM, peneliti mengikuti perhitungan yang dilakukan oleh Warfield et al., (1995) dan Gabrielsen et al., (2002) dalam Gras-Gil et al. (2016) Dimana menggunakan rumus:

$$
D_{A C C}=\beta_{0}+\beta_{1} C S R_{i t}+\beta_{2} L E V_{i t}+\beta_{3} S I Z E_{i t}+\beta_{4} R O A_{i t}+\sum \beta_{5}-\beta_{6} D I+\varepsilon_{i t}
$$

Dimana DACC adalah Discretionary Accruals, CSR adalah CSR Index, $\beta_{0}$ adalah Konstanta, $\beta_{m}$ adalah Koefisien regresi ke-m, LEV adalah Total Labiliitas akhir tahun dibagi dengan total aset akhir tahun, SIZE adalah Natural logarithm dari total asset pada tahun t, ROA adalah Laba bersih dengan total aset akhir tahun, DI adalah Dummy Industry, $\varepsilon$ adalah Error.

\section{Dependen Variabel}

Variabel dependen dalam penelitian ini adalah earnings management (EM) diproksikan dengan discretionary accruals (DACC), yang merupakan nilai dari earnings management. Untuk mengestimasi discretionary accruals, penelitian ini mengikuti perhitungan yang dilakukan oleh Warfield et al., (1995) dan Gabrielsen et al., (2002) dalam Gras-Gil et al. (2016), dimana menggunakan Modifikasi Model Jones (1991) yang meregresi total akrual dari pendapatan (REV) dikurangi piutang usaha (AR) dan ditambah dengan plant, property and equipment (PPE) lalu dibagi dengan total aset periode sebelumnya. Berikut ini cara perhitungan total accruals dari Modifikasi Model Jones, 1991 (Dechow et al. 1996):

$$
\text { Total Accrual }_{i t}=\left(\Delta C A_{i t}-\Delta \operatorname{Cash}_{i t}\right)-\left(\Delta C L_{i t}-\Delta S T D_{i t}\right)-D e p_{i t}
$$

Selanjutnya menentukan koefisien dari regresi total accrual (TAC) mengguanakan crosssectional dari model modified Jones, dimana untuk memperkirakan komponen non-discretionary dari total accrual:

$$
\frac{T A C_{i t}}{A_{j, t-1}}=\beta_{0}+\beta_{1} \frac{\Delta R E V_{i t}}{A_{j, t-1}}+\beta_{2} \frac{P P E_{i t}}{A_{j, t-1}}+\varepsilon_{i t}
$$

Menggunakan koefisien regresi diatas, non-discretionary accruals (NDCA) dapat dihitung menggunakan rumus:

$$
N D A C_{i t}=\beta_{0}+\beta_{1} \frac{\Delta R E V_{i t}-\triangle A R_{i t}}{A_{j, t-1}}+\beta_{2} \frac{P P E_{i t}}{A_{j, t-1}}
$$

Sehingga nilai discretionary accruals dapat dihitung dengan:

$$
D A C C_{i t}=\frac{T A C_{i t}}{A_{i, t-1}}-N D A C_{i t}
$$

Dimana $D A C C_{i t}$ adalah Discretionary accrual, $\triangle C A_{i t}$ adalah Perubahan total aset lancar, $\Delta \operatorname{Cash}_{i t}$ adalah Perubahan kas dan setara kas, $\Delta C L_{i t}$ adalah Perubahan total kewajiban lancar, $\Delta S T D_{i t}$ 


\section{JURNAL AKUNTANSI, Vol. 9, No. 2, November (2020)}

adalah Perubahan utang jangka panjang termasuk kewajiban lancar, $D e p_{i t}$ adalah Beban penyusutan dan amortisasi, TAC adalah Total akrual, $\beta_{0}$ adalah Konstanta, $\beta_{m}$ adalah Koefisien regresi ke-m, $\triangle R E V$ adalah Perubahan pendapatan, $\triangle A R$ adalah Perubahan piutang, PPE adalah Gross property, plant dan equipment, $\varepsilon$ adalah Error, $A_{i, t-1}$ adalah Total aset yang tertinggal, NDAC adalah Nondiscretionary Accrual.

\section{Independen Variabel}

Variabel independen dalam penelitian ini adalah corporate social responsibility (CSR). CSR diukur dengan menggunakan uji checklist terhadap 78 item pengungkapan CSR. Checklist ini berdasarkan pada penelitian yang dilakukan oleh Sembiring (2005), dimana penelitian Sembiring (2005) ini mengacu pada Global Reporting Initiative (GRI) dan disesuaikan dengan perekonomian Indonesia.

Masing-masing item akan diberikan penilaian dimana “1” jika diungkapkan oleh perusahaan atau " 0 " jika item tidak diungkapkan oleh perusahaan. Kemudian indeks CSR untuk setiap perusahaan diperoleh dengan menjumlah penilaian item setiap perusahaan dibagi dengan jumlah item performance indicator yang ditentukan. Dimana rumusnya sebagai berikut:

$$
\frac{\text { Total Jumlah nilai "1" }}{\text { Jumlah Checklist (78) }}
$$

\section{Control Variabel}

Dalam penelitian ini, variabel kontrolnya adalah Leverage, Size, dan ROA. Alasan mengapa size, leverage, dan ROA dimasukkan sebagai variabel kontrol, karena variabel-variabel tersebut dapat mempengaruhi discretionary accrual (DA). Berikut ini adalah penjelasan masing-masing variabel tersebut (Gras-Gil et al., 2016).

\section{Leverage}

Leverage (LEV) adalah alat yang digunakan untuk mengukur ketergantungan perusahaan terhadap pembiyaaan kegiatan operasi perusahaan melalui bantuan kreditur. Dengan demikian leverage dapat mencerminkan tingkat risiko keuangan. Skala pengukuran untuk leverage dengan rasio leverage (debt-to-asset ratio), yaitu rasio hutang terhadap total aset.

\section{Ukuran Perusahaan (Size)}

Size merupakan proksi dari political cost. Menurut Gray et al. (2001) kebanyakan penelitian yang dilakukan mendukung hubungan antara ukuran perusahaan dengan CSR. Hal ini berkaitan dengan teori agensi, dimana perusahaan besar yang memiliki biaya keagenan yang lebih besar akan mengungkapkan informasi lebih luas untuk mengurangi biaya keagenan (Sembiring, 2005). Skala pengukuran untuk size dengan natural logarithma total aset.

\section{Return On Assets (ROA)}

Return On Assets (ROA) adalah proksi dari profitabilitas. Penelitian oleh Dechow et al. (1995) menyatakan bahwa discretionary accruals berkorelasi dengan kinerja perusahaan. Scholten dan Kang (2012) menyatakan bahwa perusahaan dengan tingkat profitabilitas yang rendah memiliki kecenderungan lebih besar untuk melakukan EM. Begitu pula dengan sebaliknya, ketika perusahaan memiliki tingkat profitabilitas yang tinggi maka memiliki kecenderungan lebih kecil untuk melakukan EM. Sehingga Profitabilitas dapat dihitung dengan rasio ROA.

\section{Dummy Industry (DI)}

Variabel dummy yang digunakan untuk membedakan badan usaha manfaktur menjadi 3 jenis yaitu Basic Industry And Chemicals, Miscellaneous Industry, dan Customer Goods Industry. Pada kolom BASIC perusahaan Basic Industry And Chemicals akan diberi nilai " 1 " dan perusahaan Miscellaneous Industry, Customer Goods Industry akan diberi nilai "0". Pada kolom MISC Miscellaneous Industry akan diberi nilai "1" dan perusahaan Basic Industry And Chemicals, Customer Goods Industry akan diberi nilai “0”. 


\section{JURNAL AKUNTANSI, Vol. 9, No. 2, November (2020)}

\section{HASIL DAN PEMBAHASAN}

Dalam penelitian ini menggunakan obyek badan usaha manufaktur yang terdaftar di Bursa Efek Indonesia periode 2012-2016. Seluruh badan usaha manufaktur yang terdaftar di BEI akan menjadi populasi penelitian ini. Dari populasi tersebut, akan diseleksi dengan kriteria-kriteria yang telah ditentukan. Berikut ini adalah tabel pemilihan sampel untuk obyek penelitian ini:

Tabel 1. Kriteria Pengambilan Sampel untuk Obyek Penelitian

\begin{tabular}{lrrrrrr}
\hline \multicolumn{1}{c}{ KETERANGAN } & 2012 & 2013 & 2014 & 2015 & 2016 & JUMLAH \\
\hline $\begin{array}{l}\text { Badan usaha yang bergerak di sektor } \\
\text { manufaktur 2012-2016 }\end{array}$ & 143 & 146 & 146 & 146 & 148 & 729 \\
$\begin{array}{l}\text { (-)Badan usaha manufaktur yang tidak } \\
\text { memiliki annual report 2012-2016 }\end{array}$ & -21 & -11 & -12 & -11 & -20 & -75 \\
$\begin{array}{c}\text { (-)Badan usaha manufaktur yang } \\
\text { menggunakan mata uang selain }\end{array}$ & -28 & -29 & -27 & -27 & -26 & -137 \\
$\quad \begin{array}{l}\text { Rupiah } \\
\text { Total Data }\end{array}$ & 94 & 106 & 107 & 108 & 102 & 517 \\
\hline
\end{tabular}

Sumber : Data Olahan, 2017

Berdasarkan tabel di atas dapat dilihat jumlah perusahaan manufaktur periode 2012-2016 yang menjadi populasi dalam penelitian ini. Dengan jumlah 729 yang menjadi populasi, dilakukan seleksi dan didapatkan 517 perusahaan yang memenuhi kriteria dalam penelitian ini. Kemudian dilakukan pengujian dan ditemukan beberapa sampel yang outlier sehingga dilakukan pembuangan sampel tersebut. Berikut merupakan jumlah sampel yang dibuang selama pengujian:

Tabel 2. Pengurangan Sampel Karena Uji Normalitas

\begin{tabular}{lr}
\hline \multicolumn{1}{c}{ KETERANGAN } & JUMLAH \\
\hline Total Data Selama 5 Periode yang Diteliti & 517 \\
Pengurangan 2012 & 13 \\
Pengurangan 2013 & 17 \\
Pengurangan 2014 & 12 \\
Pengurangan 2015 & 13 \\
Pengurangan 2016 & 39 \\
Total Sampel & $\mathbf{4 2 3}$ \\
\hline
\end{tabular}

Sumber : Data Olahan, 2017

\section{Statistik Deskriptif}

Analisis statistik deskriptif digunakan untuk menggambarkan karakteristik dari sampel penelitian yang mewakili populasinya. Statistik deskriptif terdiri dari jumlah obsevasi, nilai minimum (minimum), nilai maksimum (maximum), nilai rata-rata (mean), serta standar deviasi untuk masingmasing variabel penelitian yang telah diukur. Hasil dari statistik deskriptif dilihat pada tabel dibawah ini:

Tabel 3. Descriptive Statistics

\begin{tabular}{llrrrr}
\hline & $\mathrm{N}$ & \multicolumn{1}{c}{ Minimum } & Maximum & \multicolumn{1}{c}{ Mean } & Std. Deviation \\
\hline DACC & 423 & -0.3508 & 0.3384 & -0.0144 & 0.1031 \\
CSR & 423 & 0.0513 & 0.5256 & 0.2162 & 0.1168 \\
LEV & 423 & 0.0372 & 2.8763 & 0.4749 & 0.3274 \\
Size & 423 & 24.6111 & 33.1988 & 28.1653 & 1.5748 \\
ROA & 423 & -0.2828 & 0.9275 & 0.0766 & 0.1133 \\
BASIC & 423 & 0 & 1 & 0.40 & 0.490 \\
MISC & 423 & 0 & 1 & 0.22 & 0.411 \\
Valid N (listwise) & 423 & & & &
\end{tabular}

Sumber: output software pengolah data, 2017 


\section{JURNAL AKUNTANSI, Vol. 9, No. 2, November (2020)}

Analisis Regresi Linier Berganda
Analisis Koefisien Determinasi $\left(R^{2}\right)$

Tabel 4. Hasil Penguian Koefisien Determinasi

\begin{tabular}{ccccc}
\hline Model & $\mathrm{R}$ & $\mathrm{R}$ Square & $\begin{array}{c}\text { Adjusted } \mathrm{R} \\
\text { Square }\end{array}$ & $\begin{array}{c}\text { Std. Error of the } \\
\text { Estimate }\end{array}$ \\
\hline 1 & $0.347^{\mathrm{a}}$ & 0.120 & 0.107 & 0.097392804929357 \\
\hline \multicolumn{3}{r}{ Sumber: output software pengolah data, 2017}
\end{tabular}

Hasil uji Koefisien Determinasi menunjukkan bahwa variabel-varianel independen yaitu CSR, levergae, size, dan ROA dapat menjelaskan variabel dependen (DACC) sebesar 10,7\%. Sedangkan 89,3\% disebabkan oleh faktor lain diluar model.

\section{Analisis Koefisien Korelasi (r)}

Tabel 5. Uji Koefisien Korelasi (r)

\begin{tabular}{|c|c|c|c|c|c|c|c|c|}
\hline & & DACC & CSR & LEV & Size & ROA & BASIC & MISC \\
\hline DACC & $\begin{array}{l}\text { Pearson } \\
\text { Correlation } \\
\text { Sig. (2-tailed) }\end{array}$ & 1 & & & & & & \\
\hline CSR & $\begin{array}{l}\text { Pearson } \\
\text { Correlation } \\
\text { Sig. (2-tailed) }\end{array}$ & $\begin{array}{r}-0.150^{* *} \\
0.002\end{array}$ & 1 & & & & & \\
\hline LEV & $\begin{array}{l}\text { Pearson } \\
\text { Correlation } \\
\text { Sig. (2-tailed) }\end{array}$ & $\begin{array}{r}-0.017 \\
0.731\end{array}$ & $\begin{array}{c}0.166^{-*} \\
0.001\end{array}$ & 1 & & & & \\
\hline Size & $\begin{array}{l}\text { Pearson } \\
\text { Correlation } \\
\text { Sig. (2-tailed) }\end{array}$ & $-0.131^{* *}$ & $\begin{array}{r}0.622^{* *} \\
0.000\end{array}$ & $\begin{array}{r}-0.062 \\
0.205\end{array}$ & 1 & & & \\
\hline ROA & $\begin{array}{l}\text { Pearson } \\
\text { Correlation } \\
\text { Sig. (2-tailed) }\end{array}$ & $\begin{array}{r}\text { DACC } \\
0.001 \\
0.988\end{array}$ & $\begin{array}{r}\text { CSR } \\
0.215^{* *} \\
0.000\end{array}$ & $\begin{array}{r}\text { LEV } \\
-0.294^{* *} \\
0.000\end{array}$ & $\begin{array}{r}\text { Size } \\
0.151^{*} \\
{ }_{*}^{*} \\
0.002\end{array}$ & $\begin{array}{r}\text { ROA } \\
1\end{array}$ & BASIC & MISC \\
\hline BASIC & $\begin{array}{l}\text { Pearson } \\
\text { Correlation } \\
\text { Sig. (2-tailed) }\end{array}$ & $\begin{array}{r}0.202^{* *} \\
0.000\end{array}$ & $\begin{array}{r}-0.022 \\
0.652\end{array}$ & $\begin{array}{l}0.040 \\
0.407\end{array}$ & $\begin{array}{r}-0.093 \\
0.056\end{array}$ & $\begin{array}{r}-0.192^{* *} \\
0.000\end{array}$ & 1 & \\
\hline MISC & $\begin{array}{l}\text { Pearson } \\
\text { Correlation } \\
\text { Sig. (2-tailed) }\end{array}$ & $\begin{array}{r}-0.290^{* *} \\
0.000\end{array}$ & $\begin{array}{r}-0.069 \\
0.156\end{array}$ & $\begin{array}{r}0.141^{* *} \\
0.004\end{array}$ & $\begin{array}{l}0.017 \\
0.724\end{array}$ & $\begin{array}{r}-0.117^{*} \\
0.016\end{array}$ & $\begin{array}{r}-0.427^{* *} \\
0.000\end{array}$ & 1 \\
\hline
\end{tabular}

Sumber : output software pengolah data, 2017 berhubungan.

Hasil uji koefisien korelasi menunjukkan bahwa variabel CSR, size dan DACC saling

\section{Uji Simultan (F-Test)}

Tabel 6. Hasil Uji Simultan (F-Test)

\begin{tabular}{lrrrrc}
\hline Model & Sum of Squares & \multicolumn{1}{c}{ df } & Mean Square & F & Sig. \\
\hline 1 Regression & 0.539 & 6 & 0.090 & 9.464 & $0.000^{\mathrm{b}}$ \\
Residual & 3.946 & 416 & 0.009 & & \\
Total & 4.485 & 422 & & & \\
\hline
\end{tabular}

Sumber: output software pengolah data, 2017 


\section{JURNAL AKUNTANSI, Vol. 9, No. 2, November (2020)}

Tabel diatas menunjukkan nilai signifikansi 0,000 $(>0,05)$ yang memiliki arti bahwa H0 ditolak. Ini berarti bahwa secara simultas variabel-varianel independen yaitu DACC, CSR, levergae, size, dan ROA memiliki pengaruh terhadap variabel dependen yaitu CSR.

\section{Uji Parsial (T-Test)}

Tabel 7. Uji Parsial (T-Test)

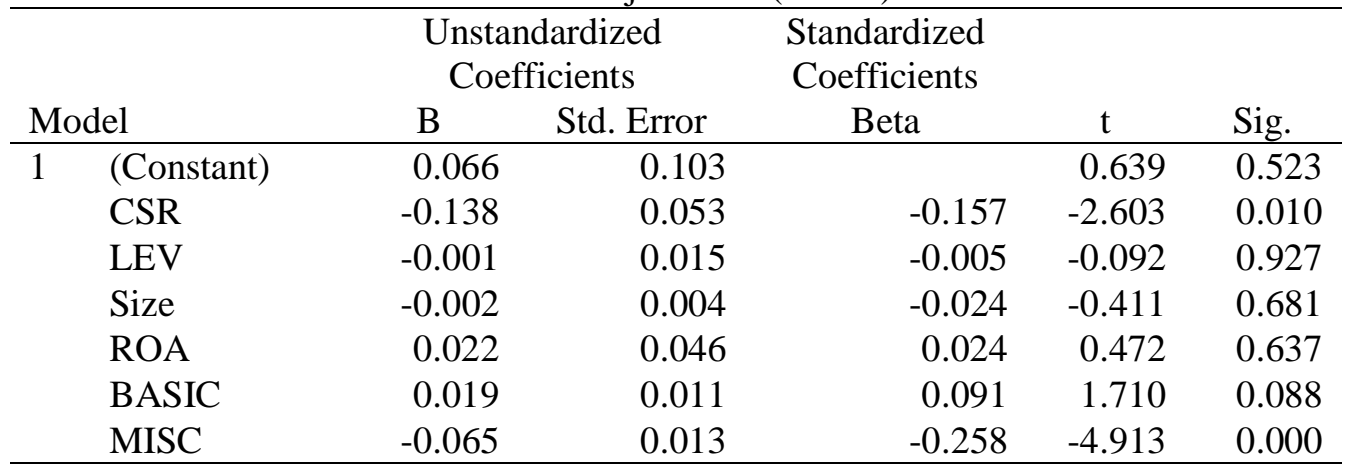

Sumber: output software pengolah data, 2017

Dari tabel di atas dapat dilihat bahwa nilai signifikansi t (Sig. t) CSR sebesar 0,010. Nilai ini lebih kecil dari tingkat signifikansi sebesar 5\% (Sig. t > 0,05), menunjukkan bahwa CSR memberikan pengaruh yang signifikan terhadap DACC. Untuk nilai koefisien regresi CSR memiliki nilai sebesar 0,138 dimana menunjukkan bahwa variabel CSR memberikan pengaruh negatif terhadap DACC. Maka dapat disimpulkan bahwa CSR selaku variabel independen memberikan pengaruh negatif terhadap DACC selaku variabel dependen, sehingga Hipotesis 1 (H1) pada penelitian ini diterima. Untuk variabel kontrol yaitu leverage, size, dan ROA tidak meempengaruhi EM.

\section{Pembahasan}

CSR memberikan pengaruh negatif signifikan terhadap EM. Hal ini menunjukan bahwa kegiatan CSR yang dilakukan perusahaan dapat menurunkan manajemen laba. Sesuai dengan stakeholder teori, kegiatan csr digunakan sebagai alat untuk memuaskan stakeholder, sehingga perusahaan tidak perlu lagi melakukan manajemen laba. Hasil ini sejalan dengan penelitian yang dilakukan oleh Gras-Gil et al. (2016) dimana merupakan penelitian acuan dalam penelitian ini. GrasGil et al. (2016) menemukan adanya hubungan negatif antara CSR dan EM, dimana dapat diartikan bahwa perusahaan yang berkomitmen terhadap CSR akan kurang terlibat dalam EM. Gras-Gil et al. (2016) menyatakan bahwa perusahaan yang banyak melakukan CSR cenderung mendorong hubungan jangka panjang dengan stakeholder daripada memaksimalkan keuntungan jangka pendek. Sehingga dalam hal ini, earning quality memiliki kaitan erat dengan CSR, terutama bertujuan untuk memenuhi kebutuhan para stakeholder.

Begitu pula dengan hasil penelitian Sembiring (2017) dan Kim et al. (2012), dimana menemukan terdapat pengaruh negatif signifikan antara CSR dengan EM. Sembiring (2017) dan Kim et al. (2012), menyimpulkan bahwa perusahaan yang melakukan CSR membuat pelaporan keuangan lebih transparan dan dapat diandalkan untuk para investor, serta memotivasi pihak manajer untuk bersikap jujur, dapat dipercaya, dan beretika. Sehingga perusahaan yang berkomitmen dalam CSR cenderung menunjukkan EM yang rendah.

Hasil penelitian ini juga sesuai dengan Wulandari (2015), Scholtens dan Kang (2012), dan Yip et al. (2011). Yip et al. (2011) menemukan pengaruh negatif antara CSR dengan EM pada perusahaan oil and gas industry. Scholtens dan Kang (2012) menyatakan ketika perusahaan dengan tingat CSR yang relatif baik cenderung lebih kecil melakukan praktik manajemen laba. Shleifer (2004) menemukan perusahaan yang memiliki komitmen CSR yang tinggi tidak akan melakukan EM yang merupakan tindakan yang melanggar etika, dan dapat merusak image perusahaan. Pengungkapan CSR mencerminkan transparansi dan menurunkan opportunistik EM, serta dapat membangun hubungan masa depan yang baik dengan lingkungan dan stakeholder. 


\section{JURNAL AKUNTANSI, Vol. 9, No. 2, November (2020)}

Leverage memiliki koefisien regresi -0,001 dan signifikansi 0,927, dimana menunjukkan bahwa leverage tidak berpengaruh terhadap EM. Hasil penelitian ini sejalan dengan Wulandari (2015) dan Rahman dan Ali (2006). Perusahaan dengan tingkat leverage yang tinggi akan terancam menghadapi resiko default, dan EM tidak dapat dijadikan sebagai mekanisme untuk menghindari default tersebut (Rahman dan Ali, 2006).

Size, memiliki koefisien regresi -0,002 dan signifikansi 0,681, dimana menunjukkan bahwa size tidak berpengaruh terhadap EM. Hasil penelitian ini sejalan dengan Sembiring (2017), dimana menemukan tidak adanya hubungan antara Size dengan EM. Hasil penelitian ini juga sejalan dengan Nasution dan Setiawan (2007), dimana menemukan size tidak berhubungan dengan EM. Perusahaan yang lebih besar cenderung kurang memiliki dorongan untuk melakukan EM dibandingkan perusahaan kecil dan perusahaan besar dipandang lebih kritis oleh stakeholder, namun jika perusahaan dengan tingkat penjualan yang tinggi bisa melakukan EM manakala perusahaan merasa perlu untuk mempertahankan tren bagus penjualan (Marrakchi, 2001 dan Kim et al, 2003)

ROA, merupakan variabel kontrol yang terakhir. ROA memiliki koefisien regresi 0,022 dan signifikansi 0,637, dimana menunjukkan bahwa ROA berpengaruh positif yang tidak signifikan terhadap variabel dependennya (DACC). Hal ini menjelaskan bahwa semakin besar tingkat pengembalian maka semakin cenderung tingkat EM akan meningkat namun tidak signifikan. Penelitian ini sejalan dengan penelitian Hastuti (2005) dan Boediono (2005) dimana menemukan DACC tidak berpengaruh signifikan terhadap ROA. Penelitian ini juga sejalan dengan Aji dan Mita (2010) dimana menemukan ROA tidak berhubungan terhadap EM, karena ketika ROA semakin tinggi maka akan semakin diperhatikan oleh publik dan probabilitas perusahaan melakukan EM lebih rendah. Hal ini juga dapat terjadi karena perusahaan lebih berfokus untuk meningkatkan kegiatan operationalnya agar dapat menghasilkan keuntungan yang lebih dari pada berfokus melakukan EM yang merupakan perbuatan yang tidak beretika (Kim et al, 2011).

Untuk variabel dummy, yaitu Dummy Industry (DI) dapat dilihat bahwa manufaktur jenis basic industry and chemicals lebih berpengaruh signifikan terhadap EM (DACC) dibandingkan dengan customer goods industry. Namun hanya berpengaruh pada tingkat signifikan $10 \%$. Sedangkan jika dibandingkan dengan manufaktur miscellaneous industry lebih berpengaruh signifikan terhadap EM dibandingkan dengan basic industry and chemicals dan customer goods industry. Jadi dapat disimpulkan bahwa manufaktur miscellaneous industry merupakan jenis manufaktur yang paling berpengaruh terhadap EM.

\section{Robustness Test}

Untuk pengujian tambahan, variabel CSR diubah menjadi variabel dummy, dimana 1 untuk perusahaan yang mengungkapkan CSR diatas rata-rata dan 0 untuk perusahaan yang mengungkapkan CSR di bawah rata-rata. Berikut merupakan hasil regresi linear berganda analisa tambahan:

Tabel 8. Uji Parsial (T-Test) Robustness test

\begin{tabular}{|c|c|c|c|c|c|c|}
\hline \multirow{2}{*}{\multicolumn{2}{|c|}{ Model }} & \multicolumn{2}{|c|}{$\begin{array}{l}\text { Unstandardized } \\
\text { Coefficients }\end{array}$} & \multirow{2}{*}{$\begin{array}{l}\text { Standardized } \\
\text { Coefficients } \\
\text { Beta }\end{array}$} & \multirow[b]{2}{*}{$\mathrm{t}$} & \multirow[b]{2}{*}{ Sig. } \\
\hline & & B & Std. Error & & & \\
\hline 1 & (Constant) & 0.001 & 0.009 & & 0.073 & 0.942 \\
\hline & DUM CSR & -0.020 & 0.010 & -0.098 & -2.096 & 0.037 \\
\hline & BASIC & 0.019 & 0.011 & 0.090 & 1.750 & 0.081 \\
\hline & MISC & -0.065 & 0.013 & -0.260 & -5.054 & 0.000 \\
\hline
\end{tabular}

Sumber : output software pengolah data, 2017

Dari tabel diatas dapat dilihat bahwa DUM CSR (Dummy CSR) memiliki signifikan t (Sig. t) sebesar 0,037. Nilai ini lebih kecil dari tingkat signifikansi sebesar 5\% (Sig. t > 0,05), dimana secara parsial menunjukkan bahwa DUM CSR memberikan pengaruh yang signifikan terhadap DACC. Untuk nilai koefisien regresi CSR memiliki nilai sebesar -0,020 dimana menunjukkan bahwa variabel DUM CSR memberikan pengaruh negatif terhadap DACC. Maka dapat disimpulkan bahwa DUM CSR selaku variabel independen memberikan pengaruh negatif terhadap DACC, dimana dapat memperkuat hipotesis 1 . 


\section{JURNAL AKUNTANSI, Vol. 9, No. 2, November (2020)}

\section{PENUTUP}

Berdasarkan hasil penelitian yang telah dilakukan, maka disimpulan bahwa ketika perusahaan meningkatkan corporate social responsibility, berfokus pada corporate social responsibility akan earnings management akan menurun. Hasil ini terbukti dari hasil analisis regresi linier yag telah dilakukan. Untuk variabel kontrol yaitu leverage, size, dan ROA tidak berpengaruh signifikan terhadap earnings management.

Penelitian ini juga melakukan penelitian tambahan dengan mengganti variabel independen utama menjadi dummy, dan dihitung dengan analisis regresi linier. dari hasil uji tambahan ini memperlihatkan bahwa hipotesis 1 diterima, yaitu corporate social responsibility berpengaruh negatif terhadap earnings management.

\section{REFERENSI}

Aji, D. Y., dan A. F. Mita. 2010. Pengaruh Profitabilitas Risiko Keuangan, Nilai Perusahaan, dan Struktur Kepemilikan Terhadap Praktek Perataan Laba Studi: Studi Empiris Perusahaan Manufaktur Yang Terdaftar di BEI. http://asp.trunojoyo.ac.id/wp-content/uploads/2014/ 03/AKMP 51.pdf. Pada 15 Oktober 2017. Pukul 16.23.

Boediono, Gideon Setyo B. 2005. Kualitas Laba: Studi Pengaruh Mekanisme Corporate Governance dan Dampak Manajemen Laba dengan Menggunakan Analisis Jalur. Solo: Simposium Nasional Akuntansi VIII.

Dechow, P.M., Richard G. Sloan, Amy P. Sweeney. 1995. Detecting Earning Management. The Accounting Review. 70(2), 193-225.

Gras-Gil, Ester, Mercedes P. Manzano, and Joaquin H. Fernandez. 2016. Investigating the Relitionship Between Corporate Social Responsibility and Earning managements: Evidence from Spain. BRG Business Research Quarterly. 19, 289-299.

Gray, Rob, Mohammmed Javad, David M. Power, C. Donald Sinclair. 2001. Social and Environmental Disclosure and Corporate Characteristic: A Research Note and Extension. Journal of Business Finance and Accounting. 28, 327-356.

Hastuti, Theresia Dwi. 2005. Hubungan antara Good Corporate Governance dan Struktur Kepemilikan dengan Kinerja Keuangan (Studi Kasus pada Perusahaan yang Listing di Bursa Efek Jakarta). Simposium Nasional Akuntansi VIII, IAI, 2005.

Horison, Muhamad Y., Yeterina W. Nugrahanti. 2014. Perbedaan Pengungkapan Corporate Social Responsibility dan Nilai Perusahaan Antara Perusahaan Dengan Manajemen Laba Tinggi dan Rendah. Seminar Nasional dan Call for Paper. 281-295.

Jones, J. 1991. “Earnings Management during Import Relief Investigations.” Journal ofAccounting Research 29, 193-228.

Kim, Y., Liu, C., dan Rhee, S.G. 2003. The Effect of Firm Size on Earning Management. Journal College of Business Administration University of Hawai. 6, 1-30.

Kim, Y., Park, M. S., \& Wier, B. 2012. Is earnings quality associated with corporate social responsibility?. The Accounting Review, 87(3), 761-796.

Kowanda, Dionysia, Rowland B. F. Pasaribu, and Akhmad Arief. 2017. Pengungkapan Tanggung Jawab Sosial Korporat Pada Emiten Manufaktur di Bursa Efek Indonesia. Jurnal Riset Akuntansi dan Keuangan. 13 (1), 1-75.

Marrakchi, S. Chtourou. 2001. Corporate Governance and Earning Management. Diunduh dari http://paper.ssrn.com/. Pada 15 Agustus 2017. Pukul 17.50.

Orlitzky, M., Schmidt, F.L., Rynes, S.L., 2003. Corporate social and financial performance: a metaanalysis. Organ. Stud. 24, 403-441.

Prior, Diego, Jordi Surroca, and Josep A. Tribo. 2008. Are socially responsible managers really ethical? Exploring the relationship between earning management and corporate social responsibility. Corporate Governance, 16(3), 160-177.

Rahman, Rashidah A., dan Fairuzana H. M. Ali. 2006. Board, Audit Committee, Culture and Earning Management: Malaysia Evidence. Managerial Auditing Journal. 21(7). 


\section{JURNAL AKUNTANSI, Vol. 9, No. 2, November (2020)}

Scholtens, B. dan C. F. Kang. 2012. Corporate Social Responsibility and Earnings Management: Evidence fron Asian Economics. Corporate Social Responsibility and Enviromental Management.

Scott, William R.. 2015. Financial Accounting Theory, Seventh Edition. Canada: Prentice Hall.

Sembiring, C. Lukita. 2017. Manajemen Laba dan Pengungkapan Tanggung Jawab Sosial Perusahaan dengan Komisaris Independendan Kepemilikan Institusional sebagai Variabel Pemoderasi. Berkala Akuntansi dan Keuangan Indonesia. 2(1), 20-41.

Sembiring, Eddy R. 2005. Karakteristik Perusahaan dan Pengungkapan Tanggung Jawab Sosial: Study Empiris pada Perusahaan yang Tercatat di Bursa Efek Jakarta. SNA VIII Solo.

Wulandari, Soliyah. 2015. The Impact of Corporate Socia Responsibility on Accrual Earnings Management and Real Earning Management. Etikonomi. 15(1), 63-74.

Yip, E., Chris Van Staden, and Steven Cahan. 2011. Corporate Social Responsibility Reporting and Earning management: The Role of Political Cost. Australasian Accounting Business and Finance Journal. 5(3), 17-34. 